\title{
Workplace change and institutional experimentation: a case study of service- sector work in Europe
}

\section{Valeria Pulignano}

KU Leuven, Belgium

\section{Paul Thompson}

University of Stirling, United Kingdom

\section{Nadja Doerflinger}

Federal Institute for Occupational Safety and Health, Dortmund, Germany

\section{Summary}

This article examines institutional experimentation by linking the dynamics of capital accumulation, the adoption of new digital technologies within the labour process, and institutional settings. Our inductive qualitative case study within the service (logistics) sector in Europe sheds light on the processes through which local stakeholders engage in workplace change through institutional experimentation. It also illustrates how and under which conditions unions can act as political agents of transformation to influence work and employment.

\section{Résumé}

Cet article examine l'expérimentation institutionnelle en mettant en corrélation la dynamique de l'accumulation du capital, l'adoption des nouvelles technologies numériques dans le processus de travail et les cadres institutionnels. Notre étude de cas qualitative inductive menée dans le secteur des services (logistique) en Europe apporte un éclairage sur les processus à travers lesquels les acteurs locaux s'engagent dans des changements sur le lieu de travail par le biais de l'expérimentation institutionnelle. Elle illustre également comment et sous quelles conditions les syndicats peuvent agir en tant qu'agents politiques de transformation en vue d'influencer le travail et l'emploi.

\section{Zusammenfassung}




\section{Keywords}

Experimentation, trade unions, workplace, institutions, power, agency, service

Corresponding author: Valeria Pulignano, Centre for Sociological Research (CESO), Faculty of Social Science, Parkstraat 45, 3000 Leuven, Katholieke Universiteit Leuven, Belgium.

Email: valeria.pulignano@kuleuven.be 


\section{Introduction}

Comparative employment and industrial relations debates within the tradition of political economy have focused on the importance of institutions in structuring work and employment, and as factors explaining employment outcomes. In particular, institutional change theory has accounted for agency and power as relevant factors when examining the interaction between large firms and employment regulatory systems (Streeck and Thelen, 2005). However, we have little knowledge on the connections between the various layers of the political economy and the forms of social agency at each distinct level. This requires the dynamics to be identified and the processes to be explored through which stakeholders at specific national, industry and organisational levels are able to engage in workplace change by experimenting with novel ways to achieve their objectives and protect their interests.

In accordance with labour process theory, agency is situated within specific labour processes where value is created and captured (Thompson and Vincent, 2010). Thus, processes of capital accumulation are important to understand how change in workplaces occurs and to explain its effects on work and employment. It is our contention that this is particularly important when considering the digital technological transformations underpinning distinct logics of capital accumulation, as the latter are at the core of new business models and point to the emergence of new practices within both emerging and traditional industries. This article examines two aspects of this development: a) how the capital accumulation dynamics embracing new digital technologies are affecting work and employment in the European logistics industry; and b) how and under which conditions are trade unions engaging (if at all) in workplace change by experimenting with novel ways to pursue their intentions and interests. The term 'novel' is used to describe situations in which workplace stakeholders take rather unconventional paths when using institutional resources to adapt to global competition. One crucial outcome of this development is that trade unions may break with the existing norms and rules of a specific institutional context, thereby redefining their relation to - or creating the conditions for the establishment of - particular institutions. We consider unions doing this as political agents of transformation, since their refusal to comply with specific norms and rules within particular institutional settings may create scope for the redefinition (or the creation) of the latter. 
Focusing on institutional experimentation, a process drawing on 'the mutual (or co-) constitution of actors and institutions' (Kristensen and Morgan, 2012: 415), this article explores its role within work and employment. In particular, it studies how workplace stakeholders engage in institutional experimentation by strategically coupling capitalist dynamics and national institutions. We examine the change underpinning the emergence of organisational forms of production and work organisation for capital accumulation, including the use of digital technology, in the parcel delivery and warehousing divisions of the global logistics firm LogCorp in Germany and Belgium. We also look at how trade unions are influenced by - as well as how they influence - this change, investigating the processes (institutional compliance and avoidance) pushing them to experiment. Specifically, we explain how and under which conditions unions can reverse the social effects generated by accumulation logics. It is our contention that this involves mobilising resources at the intersection between unions' organisational and institutional contexts. We also illustrate that those trade unions using these resources in an unconventional and novel way are the ones likely to become political agents of transformation.

Thus, our argument adds to debates on institutional change by demonstrating that the core theoretical question is not whether an institution can change through players' everyday practices with that specific institution but why and how that change can generate the conditions underpinning their capacity to become political agents of transformation. Moreover, we illustrate that the coupling of different forces of change positioned at different levels (institutional and organisational) deserves equal relevance for the study of how experimentation unfolds, showing how this change affects work and employment.

Our research questions are as follows: how do trade unions engage in workplace change through experimentation? Which factors explain their capacity to become political agents of transformation at the intersection of capital accumulation logics and different institutional settings?

The case of the logistics industry is relevant from both an empirical and analytical perspective. Logistics is a global industry characterised by a predominantly low-skilled workforce, low-quality jobs and negative working conditions (Benvegnú et al., 2018; Newsome et al., 2013; Gautié et al., in press), as reflected in the fact that levels of employment protection in the service (logistics) industry are generally less generous than in manufacturing sectors (Giraud and Lallement, 2014). In the context 
of globalisation, the logistics industry has gone through intense restructuring to increase competitiveness by reducing inventory costs, deploying 'time-compressed' logistics processes, adopting 'lean logistics' principles, and outsourcing. This has taken place at a time when more and more companies have externalised logistics as a 'non-core activity', driving up the share of independent providers in the logistics market (Wright and Lund, 2006).

The global marketplace has compelled businesses to transform into customeroriented, service-focused organisations, irrespective of the products and services they sell. Technology has become indispensable in this development, facilitating the almost exponential growth of business and offering firms an all-important competitive edge. Indeed, technology provides the opportunity for companies to offer services far beyond their primary business concept, thereby reducing their risk of losing out to competitors who have adapted their strategies to the technology-based competitive environment (Olsen and Connolly, 2000). The importance of technology has also led to considerable changes in business practices. As we will illustrate, the adoption of digital technologies and innovative business practices have provided the potential for companies to reap efficiency gains referred to as improvements in capital accumulation processes, for instance through using new digital gadgets (e.g. Google glasses or sophisticated scanning devices) (Hamel and Skarzynski, 2001).

The article is structured as follows. The first part presents the concept of institutional experimentation, discussing workplace change as resulting from processes of capital accumulation accompanying the adoption of digital technology and the emergence of new business models in logistics. The second part introduces the research context and methods and presents the findings. The third part comprises the conclusion.

\section{Institutional experimentation and capital accumulation: new business models in logistics}

Processes of capital accumulation take place through work within a wide variety of domains and through different sorts of activities. These domains and activities - as Marx clearly described - shape the labour process as distinctively 'capitalist'. Companies seek to adapt to global competition by experimenting with ways which can help capital to deal with labour market rigidities and social protections. This may require continuous improvement, i.e., building the capacity for self-correction and 
change (Sabel and Zeitlin, 2005). The process of continuous improvement focuses on features (including institutions) key to the process of capital accumulation.

A substantial number of scholarly and policy debates in organisation studies and human resource management (HRM) relate capital accumulation to highperformance work systems, performance and productivity, and workplace innovation (Appelbaum and Batt, 1994; Osterman, 1994; Jensen et al., 2013). Central to these debates is the role of effective acquisition, deployment and development of human capital in how and how much value is created, as well as the role and impact of organisational leadership and governance, and managerial approaches and practices on value-creation outcomes (Findlay et al., 2016: 3). Nevertheless, linking the analysis of capital accumulation to the emergence of new business models implies consideration of how it intersects with processes of value creation and value capture.

Value is realised in the marketplace as the result of transformation, embeddedness in a wider social structure, and capture or distribution in the form of wages, investments, dividends and retained profits. Thus, the role of labour in enhancing value creation is underpinned by labour's share in value capture (Findlay et al., 2016). Marx's analysis of the factors governing value creation sheds light on the role of capital to extend its capacity to control as well as to lower the costs of production as an essential component of value capture. Reducing the cost of shortterm contracts in the marketplace for the sake of value capture is companies' ultimate goal. This is evident as companies advance forecasting of future demand and invest capital to fuel production processes, which not only requires specific inputs but also results in delivering distinctive outputs (Agafonow, 2015).

Alongside these debates, however, there is also evidence that new business models necessitate new narratives of how value is created and captured, requiring analytical attention (Lazonick and Mazzucato, 2013). By using new technologies, for instance, companies can expand globally at astounding speed and with dramatically less investment in value-adding assets. Thus, new business models based on such technologies are emerging, offering new capabilities and competences and in turn opening up new approaches and organisational structures. Such companies engage in workplace change through experimentation, a trend particularly evident in the logistics sector for three reasons. 
First, to navigate the uncertainty created by the increasing interconnectedness of business, economic and socio-political spheres, companies in the service sector, and particularly in logistics, have cut back their investment in physical assets and onthe-ground operations and invested in digital technology to reach out quickly to customers. Secondly, logistics has evolved from a passive, cost-absorbing function to that of a strategic factor providing a unique 'competitive advantage' (Bhatnagar and Teo, 2009). This has changed existing cost structures underpinning the economic growth linked to the new business models. Thirdly, logistics companies are nowadays part of a nested set of so-called 'complex adaptive systems'. Flexible global production requires efficient logistics. Goods need to be moved quickly and surely, at low cost and potentially over long distances. This requires modern information and communication technology constantly to monitor and steer the flow of goods. Hence, there is increasing reliance on logistics companies, not only to move products and materials, but also to assist with new production requirements and customer needs. What is important for business is to reach out and serve customers around the world in an easier and cheaper way. Moreover, by collaborating with developers and technology partners, logistics companies have introduced innovative services more frequently and upgraded existing ones.

How do changes in business practices supported by the use of new technologies impact strategies for capital accumulation? Bhattacharya et al. (2017) illustrate how new technologies and the growing interconnectivity of devices enable companies to add value to their products globally through software features, as opposed to delivering features only through a product's hardware, sold locally. In the process, these collaborations transform 'value chains' into 'value networks', in which value addition is no longer sequential and one-dimensional but rather a continuous and multi-dimensional activity, whereby a global 'adaptive system' can embrace many industries, coordinate services and provide innovative solutions to a wide range of customers (both individuals and organisations). As the next sections illustrate, such transformations are at the core of LogCorp, a company which has invested heavily in providing innovative services to customers with a view to expanding relationships and networking to gain competitive advantage, while at the same time changing work and employment conditions.

\section{Research design and methods}


Adopting an inductive approach, we conducted a comparative qualitative case study on the parcel delivery and warehousing services offered by LogCorp, a multinational company with subsidiaries in Belgium and Germany. LogCorp employs several hundred thousand staff globally and is a key player in the German and Belgian markets.

The selection of Belgium and Germany was based on their differing collective bargaining and representation systems. Whereas uncoordinated decentralisation with derogation capacity is a distinct feature of the German industrial relations system (including local negotiations on the use of external and internal flexibility), Belgium's system features the centralised coordination of collective agreements with hardly any derogation possibilities. Moreover, in addition to the consultation and information rights typical of employee representation systems in both countries, works councils in Germany have co-determination rights. We expect these differences to matter when explaining employment outcomes as the reflection of how experimentation unfolds at the intersection of capital accumulation dynamics and institutional settings. In particular, we hypothesise that the derogation capacity typical of the German system of decentralised bargaining may offer greater scope for workplace adaptation and experimentation than in Belgium due to German employers' relatively stronger discretionary power (Baccaro and Howell, 2017). However, we also expect Germany's co-determination law to constrain this power, with works councils' veto rights imposing negotiations and consequently fostering consensual management and labour relationships (see Table 1).

Guided by the research questions, the selection of LogCorp and its two business divisions (warehousing and parcel delivery) follows the principle of purposeful sampling, whereby information-rich cases are selected to generate casebased in-depth insights rather than empirical generalisations (Patton, 2002). Cases were selected based on an analysis of secondary data and intense consultation and discussion with four experts from the International and European Transport Worker Federations (ITF/ETF) and UNI Europe.

Table 1. Country-based institutional features. 


\begin{tabular}{|c|c|c|}
\hline $\begin{array}{l}\text { Collective } \\
\text { bargaining }\end{array}$ & $\begin{array}{l}\text { Uncoordinated } \\
\text { decentralisation }\end{array}$ & Centralised coordination \\
\hline $\begin{array}{l}\text { Derogation from } \\
\text { sectoral } \\
\text { agreements }\end{array}$ & $\begin{array}{l}\text { Possible via 'opening } \\
\text { clauses' }\end{array}$ & Hardly any possibilities \\
\hline Union density & $17 \%(2016)$ & $54.2 \%(2015)$ \\
\hline $\begin{array}{l}\text { Representation } \\
\text { structures }\end{array}$ & $\begin{array}{l}\text { Information, consultation, } \\
\text { co-determination (veto } \\
\text { power) }\end{array}$ & $\begin{array}{l}\text { Information, consultation (no } \\
\text { co-determination) }\end{array}$ \\
\hline $\begin{array}{l}\text { Working-time } \\
\text { regulation }\end{array}$ & $\begin{array}{l}\text { Local-level regulation } \\
\text { possible through opening } \\
\text { clauses }\end{array}$ & $\begin{array}{l}\text { Sectoral regulation; limited } \\
\text { derogation possibilities }\end{array}$ \\
\hline $\begin{array}{l}\text { Agency work } \\
\text { regulation }\end{array}$ & $\begin{array}{l}\text { Co-determination does not } \\
\text { include veto right on the use } \\
\text { of agency work }\end{array}$ & $\begin{array}{l}\text { No co-determination and no } \\
\text { veto rights }\end{array}$ \\
\hline
\end{tabular}

Source for union density: OECD.Stat.

We collected different kinds of primary data between 2017 and 2019 to identify and analyse the dynamics and ways in which value logics affected work and employment in the business divisions. Data resulted from semi-structured interviews with experts $(n=6),(H R)$ managers $(n=17)$, local employee representatives $(n=5)$ and workers $(n=15)$, each lasting one to three hours. Respondent selection was conceptually driven although we also used snowball sampling to identify interviewees throughout the data collection process (Patton, 2002). In addition, we used ethnographic methods including observations of workers and work processes in four sites (warehouses and logistics hubs) for about seven days. We participated in three trade union meetings in the logistics sector, enabling (informal) talks with industry experts, employee representatives and external experts including journalists, and in the 2019 annual shareholder meeting of LogCorp. To complement our primary data and triangulate information gathered in different ways, we also analysed a range of secondary material, including data and reports on the logistics industry, articles published in specialist logistics journals and newspapers, as well as 
(annual) company and union reports. NVivo was used to structure and analyse the collected data.

\section{The case of LogCorp}

Workplace transformation and effects on work and employment

A growing number of companies have outsourced warehousing in recent years, generating a (low-margin) market for providers like LogCorp, a company in competition with other contract logistics firms offering low-price warehousing operations. Logistics management is constantly seeking to increase profit margins by enhancing customers' dependency through taking over ever-larger parts of a customer's value chain. Investments in service innovation are the way in which LogCorp attempts to increase its profitability and strengthen customer retention. As a result, LogCorp has been transformed from a 'usual supplier' into an innovative partner for customers. This transformation implies the constant development of novel service solutions to increase profits, while enabling cost and/or time savings and the introduction of lean and/or more efficient operations. A country manager put it this way: 'What is changing is the amount of services we add to existing business in warehousing'. These services enable LogCorp 'to establish a special relationship with the customer [...] We show our customers that we can offer more than just warehousing [...] very often customers ask what else they could do to reduce costs, from delivery to distribution, consultation with other customers and so on [...] we provide an answer to all this'. Thus, warehousing plays an active role in service innovation through optimising the production and service processes offered. By building up a long-term partnership based on service innovation, LogCorp attempts to sustain profitability in the long run.

At the same time, its lean and standardised production processes allow LogCorp to adjust promptly to market fluctuations. Digital technology is used to increase productivity by steering the circulation of goods. In particular, resource planning and monitoring software as well as modern scanning devices constantly track the flow of goods, ensure transparency within the labour process and allow possible problems in the flow of goods to be detected in real time. New scanning systems and devices (vision picking through Google glasses) facilitate picking and enable performance to be measured constantly, as well as tracking each worker's 
steps or actions. Workers are encouraged to develop new ideas on how to reduce problems, promoting additional efficiency gains. According to a company expert, the lean management system used in warehousing brings 'productivity gains of at least 5 per cent' and, where individual performance measurement is possible, LogCorp can even reach 'around 10 per cent'. The result is increased work intensity. Moreover, technology and process standardisation limit workers' control over the work processes. Technological gadgets steer workers' tasks and, at the same time, allow for the monitoring of key performance indicators like the minimum number of picks per hour. When workers do not achieve their target rate, this is discussed in weekly one-to-one 'feedback' meetings with team leaders. In sum, process optimisation in accordance with lean logistics principles fosters a high-performance work culture, concomitant with increased work intensity and decreased levels of control for employees.

Service innovation also plays a key role in the parcel delivery division, a business driven by the expansion of e-commerce. Such innovations aim at cutting costs, strengthening the company brand and increasing customer convenience. According to the vice president, the division's core aims are 'delivery with speed, high quality and low costs'. Thus, a number of new delivery options (timeframe, same-day, evening, drop-off delivery, or delivery through package stations) have been developed and implemented to offer customers their preferred delivery option. As one local manager pointed out, this brands the company as an innovator: 'We direct a customer's choice [...] we ask him/her where to deliver because s/he bought a service including delivery to the home address [...] this helps us brand our product, something we need to do to gain competitive advantage'. While providing several options for the customer strengthens the brand and underlines innovativeness, it also limits the number of costly unsuccessful deliveries requiring at least one further delivery attempt.

The division's customer-centric strategy is underpinned by digital technology. Track-and-trace software enables customers to track the location of their shipment at any time. To optimise delivery, couriers now receive their algorithmically optimised route planning every morning on their tablets (routes were previously at their discretion). The result is reduced autonomy for workers while at the same time ensuring speedy deliveries and cutting costs. In the same vein, several couriers in Germany reported that managers and customers can see their position through 
track-and-trace software and can measure performance levels through the number of scans or deliveries per hour in real time. Therefore, couriers hesitate to take breaks which management can 'see' through checking the position of the van and the number of minutes without movement, delivery or scanning activity. This again leads to work intensification.

Thus, offering innovative solutions to customers based on the development of new services underpins the process of capital accumulation in logistics. Specifically, positioning the company as an innovator strengthens the corporate brand. In the same vein, customer retention is strengthened by building up a partnership through taking over ever-larger parts of a customer's value chain. Overall, this ensures capital accumulation in the long run. At the same time, digital technology affects work, particularly because it is used to measure performance and cut costs. As the next section illustrates, this process is contested since capital accumulation processes are not institutionally neutral. On the one hand, businesses are continually searching for novel ways to align with existing institutions (institutional experimentation) to guarantee and increase profitability. On the other hand, labour may attempt to reverse the social outcomes of institutional experimentation by presenting itself as a political agent of transformation in those cases in which it breaks with conventional rules and norms typical of the national institutional context it operates in. However, in all cases success remains dependent on labour's capacity to use the available power resources at the intersection between organisational and institutional contexts.

\section{Institutional experimentation}

Employment outcomes within and across the German and Belgian warehousing and parcel delivery divisions reflect the different stakeholders' attempts to try out ways to control the terms and conditions of employment by building on existing regulatory structures and institutions. Though the outcome can be advantageous for employers and trade unions alike, most of our cases show a general '(re)alignment of the institutional logic with capital accumulation' (Pulignano et al., 2019: 14). Within this context, labour's capacity to respond is often contingent upon the institutional and organisational resources which trade unions can wield within each workplace. We observe two patterns of experimentation, each relating to the dynamics of capital 
accumulation in warehousing and parcel delivery. The identified patterns are backed by evidence from the cases in Belgium and Germany.

'Institutional compliance' is observed in warehousing. Process optimisation, lean management and digital technologies support management in handling volume fluctuations, a key feature of warehousing. Customers expect the division to provide high levels of flexibility as this ensures timely solutions for capital accumulation. The number of agency workers has been reduced sharply in the German warehousing division. Previously, they were a cheap and flexible source of labour due to the relatively substandard collective agreements applying to the agency sector. However, due to recent amendments to German law, agency workers now enjoy equal pay and entitlements similar to those of permanent workers after nine months of employment. This is why warehousing management in Germany now prefers to use working-time flexibility to deal with demand unpredictability in a cost-effective way. This requires an opening clause in the sectoral agreement allowing local solutions to be negotiated by management and the works council through codetermination. In the context of this regulation, higher levels of working-time flexibility through working-time corridors, fluctuating weekly working hours and working-time accounts have already been negotiated in a number of German warehouses. As a result, costly overtime premiums can be avoided since there is no defined number of weekly working hours anymore. One local manager put it this way: 'Such agreements are of particular importance as customers can cause high fluctuations in the number of picks, and picks are very labour intensive. Higher degrees of flexibility are key to increasing our productivity'. Thus, flexible working-time arrangements reflect management's continuous search to align the existing regulatory setting in Germany with warehousing's distinct accumulation logics. However, after having complied with management's request for working-time flexibility, the works council in the investigated warehouse opposed management's request for further flexibility, stating that this would 'overburden the employees by increasing the level of unpredictability in working hours'. Local negotiations on alternative working-time arrangements providing higher levels of control for employees thus got bogged down, as the works council refused to continue negotiations under co-determination laws. In so doing, the works councils expressed their discontent with management's request to increase flexibility, preferring instead to pass the case on to their lawyers. Court proceedings have already lasted more than a year and was still ongoing at the 
time we collected the empirical data, with visible effects on the workplace social climate and challenging the spirit of compromise inherent to the German system.

In Belgium, warehousing meets flexibility requirements via a mix of a limited number of agency workers and a certain working-time flexibility on the part of fulltime workers, thereby complying with the regulations of the Belgian institutional framework. In recent years, the number of agency workers has been reduced due to local union demands. Although equal pay and equal treatment of agency workers are stipulated by law, the unions wanted to limit the use of agency work to promote stable employment. In particular, they used a combination of organisational (high membership levels in warehouses) and institutional (encompassing institutions) resources to negotiate a local agreement stating that agency work should only be used in situations of unpredictable demand fluctuations, and that the number of agency workers should not exceed 10 per cent . One manager added: 'We negotiated a collective agreement stating that every agency worker needed to be given a temporary contract after 120 days. This means we don't use these people for too long without giving them any perspective'. Nevertheless, local unions stated that only a very limited number of agency workers had received a contract with LogCorp: 'The business is volatile, and customers may leave [...] management even blames us for not being able to offer longer contracts because the collective agreement prevents them keeping on these workers as agency workers for a longer period'. To gain flexibility, management has invested in multi-skilling to enable job rotation. In contrast to Germany, working-time flexibility can only be used within clearly defined limits in Belgium. Occasionally, in cases of high workloads, employees may be asked to work one to two extra (paid) hours a day but there is no pressure from management as local unions, backed by strict regulations on working overtime, are successful in preventing staff from overworking.

'Institutional avoidance' has emerged in parcel delivery due to the growing pressure on parcel prices and internal costs. In the 2010s in Germany, management decided to set up a separate legal entity for parcel delivery to strengthen LogCorp's position vis-à-vis competitors which mostly outsource delivery to (foreign) subcontractors, operating under different, usually cheaper, conditions. Although the new legal entity for parcel delivery applied the same regional sectoral collective agreements, it did not sign up to the advantageous 'in-house' LogCorp agreements. During a trade union meeting, we talked to several workers who transferred to the 
new entity on being offered a permanent contract. They pointed out that they had had to accept a 25 per cent pay cut, as wages within the new entity were solely based upon regional sectoral agreements. Furthermore, workers mentioned increased working-time flexibility as well as differences in the amount of holidays and pay premiums for weekend work, all to the detriment of their motivation. Moreover, the creation of the new entity negatively impacted workers' solidarity by segmenting the workforce and generating inequality in working conditions between different groups of couriers.

Despite a number of attempts (including very visible strikes involving all groups of couriers which were not beneficial to LogCorp's reputation) to prevent the setting up of the new legal entity, local unions had no mandate or veto right to stop it happening. Once the new entity was set up, the unions sought to organise workers to support the formation of works councils and then to follow a strategy of progressively regulating working conditions to close the gap between couriers employed by the different entities. According to one unionist 'we organised the workforce within the new entity to be able to use membership as resource'. Subsequently, works councils were set up to improve workers' bargaining power visà-vis management. Thus equipped with wide-reaching co-determination rights, works councils in various sites were able to negotiate better local working conditions relatively quickly, gradually closing the gap, as summarised by one unionist: 'We need works council structures so that we have something to start with, and obviously, to maintain what we have and achieve better results through collective bargaining in the long run'. This strategy has been successful, with LogCorp recently announcing that the new legal entity will be reincorporated into the existing parcel division. According to local unions, this is their success: their fight for a mandate and subsequent local engagement to regulate working conditions led to nearly equal cost structures in both entities, doing away with the need for the new entity.

In Belgium, LogCorp has a similar strategy to avoid the advantageous inhouse collective agreements being used in competition with companies relying entirely on cheaper foreign subcontractors for parcel delivery. This time, instead of setting up a new entity as in Germany, management in Belgium increased the use of so-called market service providers, external companies taking over parts of the delivery chain at lower internal costs to sustain capital accumulation. The Belgian unions are not in favour of such practices as 'those people earn way less than our in- 
house couriers. The managers want them to perform equally well, but they don't want to pay for it'. A sectoral expert reports cases of 'bogus self-employment' among the providers used by LogCorp and generally underlines the prevalence of negative working conditions, including high work intensity, long hours and low pay. To reverse the downward spiral in working conditions, Belgian local unions engaged in regulating them despite the absence of a mandate directly to negotiate employment within external providers. The local unions in Belgium were thus able to limit the use of market service providers in LogCorp. A recently concluded agreement envisages 'that a minimum of 70 per cent of the workload is to be handled by our own personnel, and a maximum of 30 per cent by external providers', according to a local unionist. Management consented because of concerns about branding and possibly adverse reputational effects, affecting value creation and value capture and capital accumulation.

\section{Discussion and conclusion}

The theoretical and empirical challenge at the core of this article has been to identify and explain the processes of institutional experimentation by linking dynamics of capital accumulation, the adoption of digital technology within the labour process, and institutional settings. The European logistics industry served as a case study due to the prevalence of novel business models embracing digital workplace technology. Rather than viewing institutional configurations as given, we applied an agency perspective to identify the processes through which trade unions shape institutions when dealing with management across and within different contextual settings, including national and organisational (the multinational's business divisions) settings. This required examination of how unions regain control over the labour process by creating and levering institutional and associational power resources strongly to represent workers' interests within digitalised areas of work and employment.

We find two processes operating at the intersection between organisational and institutional levels: institutional avoidance and institutional compliance. These processes explain how unions engage in workplace change through experimentation by complying with (through exploiting) and/or avoiding (through circumventing) specific regulatory settings in both warehousing and parcel delivery. Moreover, we show how unions are able to drive this change, thereby becoming political agents of 
transformation. In particular, we observe that this is influenced by (1) the dynamics of capital accumulation as part of the mechanisms of control put in place by organisations; and (2) national industrial relations settings. Indeed, it is at the intersection between the labour process and institutional settings that we observe processes of institutional compliance/exploitation and institutional avoidance/circumvention, setting the conditions for workplace players to potentially become agents of transformation. Hence, our notion of experimentation breaks with institutional change literature through not focusing on how institutions and institutional change contribute to structuring work and employment. Instead, we use a micro-political economy of work approach to explain the way in which capital accumulation dynamics and institutional settings account for work and employment effects, illustrating how labour and management shape these effects by organisational innovation, such as introducing new services and branding strategies; and by developing ways to align with institutional settings through institutional experimentation processes, i.e., compliance and avoidance.

In particular, findings illustrate that management seeks advantageous institutional alignment with the processes of value creation and value capture and capital accumulation by exploiting and/or circumventing specific regulatory settings in both warehousing and parcel delivery (Pulignano et al., 2019). Thus, capital accumulation dynamics shape the means of institutional alignment, for example by enhancing capital's capacity to deal with labour market institutional rigidities and social protections at the lowest risk. However, institutional alignment also creates space for labour to respond to capital's strategies by experimenting with better working conditions. Our argument is that this requires unions to invest capacity in closing institutional gaps which have enabled employers to circumvent and/or avoid existing regulatory structures in the first place. We observe that in both warehousing and parcel delivery in Germany, unions pushed through workers' interests in an unconventional and novel way. Specifically, in warehousing the unionised works council refused to give its consent when management's flexibility requests would have meant high levels of working-time unpredictability for the workforce. Hence, the works council engaged in workplace change through stopping local negotiations with management despite the fact that co-determination is inherently based upon consensual management-labour relationships in Germany. By contrast, local unions active in parcel delivery in Germany first resorted to industrial action and then 
organised the workforce in the new legal entity created by LogCorp as a way to put pressure on the company and to gain a mandate to represent and bargain for the workers in the new externalised unit. Local negotiations were successful in bridging the gaps in working conditions between the internal workforce employed within LogCorp and the external one created in the new legal entity. These local negotiations also helped rebuild worker solidarity and re-establish labour power between the two segments of the workforce (Doellgast et al., 2019). Conversely, local trade unions in Belgium regained control over the labour process by levering the existing institutional legacies of centralised collective bargaining and high union density to protect and enforce workers' interests within the digitalised parcel delivery and warehousing environment. Trade unions thus used institutional (encompassing sectoral bargaining) and associational power resources to limit the use of agency work in warehousing, while encompassing bargaining structures were used to limit substantially management's use of market service providers in parcel delivery (to a 30 per cent maximum).

The empirical evidence shows how trade unions in Germany and in Belgium in warehousing and parcel delivery have adopted strategies to adapt to aspects related to existing institutional legacies with a view to rejecting the rules of the game imposed by the logics of capital accumulation underpinning business models in the different divisions of the investigated logistics company. Trade unions, equipped with resources at the intersection between their organisational and institutional contexts, have been successful in opposing capital's attempts to circumvent and/or exploit existing institutions. Moreover, the cases indicate how trade unions have used organisational and institutional resources to engage in experimentation. In particular, they demonstrate that, first, trade unions have identified the causes of bad working conditions; and, second, that they have experimented with different ways to improve these conditions. Nevertheless, transnational and national comparisons also shed light on empirical differences and unexpected outcomes. In Germany, experimentation implies that trade unions and works councils have broken with the norms surrounding country-specific institutional paradigms such as co-determination, for example in warehousing in Germany. In addition, they have used industrial action, followed up by organising strategies, a course which may sound unconventional within a context traditionally characterised by legal rights of co- 
determination aimed at guaranteeing social peace, as witnessed by the parcel delivery strike in Germany.

Conversely, trade unions in Belgium have mainly strengthened their institutional legacies, i.e., centralised collective bargaining and relatively high levels of union density. How can we explain this difference? As indicated, it can be argued that the uncoordinated decentralised industrial relations setting in Germany sees employers enjoying relatively larger discretion (Baccaro and Howell, 2017) in their attempts to control the labour process, using existing institutional loopholes to foster and support capital accumulation. However, evidence shows that labour unions 'equipped with resources at the intersection between their organisational and institutional contexts' can successfully oppose all this, regaining control over work and employment.

This implies that it cannot be taken for granted that all trade unions engaging in experimentation become agents of political transformation. In other words, it is not automatic for trade unions engaging in experimentation to be agents of political transformation. Being such an agent requires 'out of the box' thinking and 'reflexiveness'. It also implies a capacity to operate in a context stimulating such reflexive and unconventional ways of thinking. Specifically, we agree here with Kristensen and Morgan (2012) that unions' capacity to become political agents of transformation may be affected by institutions becoming more 'adaptable' and 'experimental': for example, in the German case of warehousing, works councils deciding to break with established norms under co-determination law. This indicates that conceptualising institutional experimentation may require detailed consideration of the dynamic and complex interaction between stakeholders and institutions. This is increasingly challenging due to the continually changing aspects of the surrounding socio-economic and institutional environment in which stakeholders operate and will continue to operate in the future.

\section{Acknowledgements}

The authors are grateful to the following organisations for funding the research published in this article: the Flemish Research Council FWO, KU Leuven and the European Research Council (ERC). 


\section{Funding}

This research was developed in the framework of three interlinked research projects financed by the Flemish Research Council FWO [project number G071716N]; KU Leuven C1 grant [number C14/16/015] and by the European Research Council (ERC) under the European Union's Horizon 2020 research and innovation programme [grant agreement number 833577].

\section{References}

Agafonow A (2015) Value Creation, Value Capture, and Value Devolution: Where Do Social Enterprises Stand? Administration \& Society 47(8): 1038-1060.

Appelbaum E and Batt R (1994) The new American workplace. Ithaca: Cornell University Press

Baccaro L and Howell C (2017) Trajectories of Neoliberal Transformation: European Industrial Relations Since the 1970s. Cambridge: Cambridge University Press.

Benvegnú C, Haidinger B and Sacchetto D (2018) Restructuring Labour Relations and Employment in the European Logistics Sector. Unions' Responses to a Segmented Workforce. In: Doellgast, V, Lillie N and Pulignano V (eds) Reconstructing Solidarity. Labour Unions, Precarious Work, and the Politics of Institutional Change in Europe. Oxford: Oxford University Press, pp. 83-104.

Bhattacharya S, Wainwright D and Whalley J (2017) Internet of Things (IoT) enabled assistive care services: Designing for value and trust. Procedia Computer Science 113: 659-654.

Bhatnagar R and Teo C (2009) Role of logistics in enhancing competitive advantage: A value chain framework for global supply chains. International Journal of Physical Distribution \& Logistics Management 39(3): 202-226.

Doellgast V, Lillie N and Pulignano V (2018) Reconstructing Solidarity. Labour Unions, Precarious Work, and the Politics of Institutional Change in Europe. Oxford: Oxford University Press.

Findlay P, Lindsay C, McQuarrie J, Pascoe-Deslauriers R, Findlay J and Smart A (2016) Networks and collaboration: driving fair, innovative and transformative work 
in Scotland. Available at:

https://innovatingworks.org.uk/dist/assets/FITwork Y1 Research Briefing 2.pdf (accessed 12 June 2019).

Gautié J, Jaehrling K and Perez C (in press) Neo-Taylorism in the (early) digital age: workplace transformations in French and German Retail warehouses. ILR Review.

Giraud $O$ and Lallement M (2014) Les conflits du travail en Allemagne: nouvelles formes, nouveaux enjeux. Critique Internationale 65(4): 65-83.

Hamel G and Skarzynski P (2001) Innovation: the new route to wealth. Special Feature. Journal of Accountancy. Available at:

https://www.journalofaccountancy.com/issues/2001/nov/innovationthenewrouteto wealth.html) (accessed 6 November 2019).

Jensen JM, Patel PC and Messersmith JG (2013) High-performance work systems and job control: consequences for anxiety, role overload, and turnover intentions. Journal of Management 39(6): 1699-1724.

Kristensen PH and Morgan G (2012) From Institutional Change to Experimentalist Institutions. Industrial Relations: A Journal of Economy and Society 51(1): 413437.

Lazonick W and Mazzucato M (2013) The risk-reward nexus in the innovationinequality relationship: who takes the risks? Who gets the rewards? Industrial and Corporate Change 22(4): 1093-1128.

Newsome K, Thompson P and Commander J (2013) You Monitor Performance at Every Hour: Labour and the Management of Performance in the Supermarket Supply Chain. New Technology, Work and Employment 28(1): 1-15.

Olsen MD and Connolly DJ (2000) Experience-based Travel: How Technology Is Changing the Hospitality Industry. Cornell Hotel and Restaurant Administration Quarterly 41(1): 30-40.

Osterman P (1994) How Common is Workplace Transformation and Who Adopts it? ILR Review 47(2): 173-188.

Patton MQ (2002). Qualitative research and evaluation methods. 3rd ed. Thousand Oaks: Sage.

Pulignano V, Thompson P and Doerflinger N (2019) New Business Models and Value Logics: A Case-based Comparison of Multinational's Subsidiaries in Logistics. Paper Presented at the Mini Conference on Digital Technology, SASE conference, June 2019, New York. 
Sabel CF and Zeitlin J (2005) Neither Modularity nor Relational Contracting: InterFirm Collaboration in the New Economy: Inter- Firm Collaboration in the New Economy. Enterprise and Society 5(3): 388-403..

Streeck W and Thelen K (2005) Beyond Continuity. Institutional Change in Advanced Political Economies. Oxford: Oxford University Press.

Thompson P and Vincent S (2010) Labour process theory and critical realism. In: Thompson P and Smith C (eds) Working Life: Renewing Labour Process Analysis. Critical Perspectives on Work and Employment. London: Palgrave Macmillan, pp. 47-69.

Wright $\mathrm{C}$ and Lund $\mathrm{J}$ (2006) Variations on a lean theme: work restructuring in retail distribution. New Technology, Work and Employment 21(1): 59-74. 